\title{
Supervisi Kepala Sekolah dalam Meningkatkan Kompetensi Pedagogi di Masa Pandemi Covid 19
}

\author{
Mohamad Mustari ${ }^{\bowtie}$ \\ Pendidikan Pancasila dan Kewarganegaraan, Universitas Mataram, Indonesia \\ DOI: $\underline{10.31004 / \text { obsesi.v6i3.1963 }}$
}

\begin{abstract}
Abstrak
Supervisi akademik kepala sekolah dilakukan untuk mengontrol pembelajaran yang dilaksanakan guru yang akan menjamin mutu layanan pendidikan. Tujuan penelitian ini adalah untuk menjelaskan pengaruh supervisi Kepala Sekolah dalam meningkatkan kompetensi pedagogi pendidik di masa pandemi Covid 19 di TK Dahlia Darmaji Kabupaten Lombok Tengah dengan 10 orang guru pada tahun pelajaran 2020/2021 sebagai total sampel. Pengumpulan data melalui penyebaran angket tentang supervisi kepala sekolah terhadap kompetensi pedagogik yang selanjutnya diolah dengan SPSS versi 17.00. Hasil penelitian ini menunjukan bahwa adanya perubahan kompetensi pedagogi guru dan mutu layanan pendidikan melalui supervisi akademik kepala sekolah. $42 \%$ perubahan kompetensi pedagogi guru, dimana adanya peningkatan kemampuan guru dalam menyusun perencanaan pembelajaran, memahami dan memantapkan penguasaan materi pembelajaran, pengelolaan kelas dan pemanfaatan waktu, dan berkomunikasi dengan peserta didik dengan baik. Supervisi kepala sekolah juga mempengaruhi mutu layanan pendidikan sebanyak $42,1 \%$.
\end{abstract}

Kata Kunci: supervisi; kepala sekolah; kompetensi pedagogi.

\begin{abstract}
The principal's academic supervision is carried out to control the learning process carried out by the teacher which ensures the quality of educational services. The purpose of this research is to explain the effect of Principal's supervision in improving the pedagogical competence of educators during the Covid 19 pandemic at Dahlia Darmaji Kindergarten, Central Lombok Regency with 10 teachers in the 2020/2021 school year as the total sample. Collecting data through the distribution of questionnaires regarding the supervision of school principals on pedagogic competencies which were then processed with SPSS version 17.00. The results of this study indicate that there is a change in the pedagogical competence of teachers and the quality of education services through the academic supervision of the principal. $42 \%$ changes in teacher pedagogical competence, where there is an increase in the ability of teachers in preparing lesson plans, understanding and strengthening mastery of learning materials, class management and time utilization, and communicating with students well. Principal supervision also affects the quality of education services as much as $42.1 \%$.
\end{abstract}

Keywords: supervision; headmasters; pedagogic competency.

Copyright (c) 2022 Mohamad Mustari

$\triangle$ Corresponding author :

Email Address : mustari@unram.ac.id (Mataram, Indonesia)

Received 17 October 2021, Accepted 16 December 2021, Published 14 January 2022 


\section{PENDAHULUAN}

Dampak pandemi virus Corona 2019 (Covid-19) kini mulai menyebar ke dunia pendidikan (Warmansyah, 2020), terbukti di Indonesia, Presiden Joko Widodo menghimbau masyarakat untuk "bekerja, belajar dan ibadah di rumah". Akibatnya kebijakan pemerintah untuk work from home memberi dampak yang signifikan yakni menimbulkan krisis ketahanan ekonomi keluarga (Wiresti, 2020). Hal ini dilakukan untuk membatasi penyebaran virus. Beberapa pemerintah daerah juga memutuskan untuk merumahkan siswa dan menerapkan metode pembelajaran dengan sistem daring. Salah satunya adalah provinsi Nusa Tenggara Barat (NTB), yang telah menetapkan libur sekolah sejak tanggal 14 Maret 2020 dan terus diperpanjang sampai saat ini hingga bulan Juni 2020 kemudian dilanjutkan dengan kebijakan pembelajaran daring tanpa tatap muka hingga saat ini. Kebijakan yang diambil pemerintah secara mendadak menimbulkan berbagai permasalahan dalam bidang pendidikan, karena tidak semua sekolah siap untuk menerapkan metode pembelajaran dengan daring.

Supervisi akademik erat kaitannya dengan penilaian kinerja guru dalam pembelajaran, sehingga kompetensi guru harus selalu ditingkatkan. Kegiatan awal kepala sekolah selaku supervisor memusatkan perhatian pada perangkat pembelajaran, maupun skenario pembelajaran yang akan diterapkan. Pada tahap kegiatan inti kepala sekolah selaku supervisor mengamati : penguasaan kelas baik ketika memimpin secara klasikal maupun jika siswa terbagi dalam kelompok-kelompok. Mengamati media dan alat pembelajaran yang dipakai apakah relevan dengan materi pembelajaran, apakah mampu mendukung penjelasan guru, serta apakah mempermudah siswa memahami materi. Kegiatan penilaian mengamati apakah sesuai dengan jenis tagihan yang seharusnya, sesusai dengan indikator dan kompetensi yang diharapkan. Dalam hal ini, supervisi kepala sekolah itu sangat penting dan berpengaruh terhadap mutu pendidikan (Suwartini, 2017).

Faktor komponen ketenagaan (khususnya profesionalitas guru) memegang peranan penting dalam peningkatan mutu pendidikan (Das, 2015). Permasalahan peningkatan mutu pendidikan merupakan kondisi yang penting dan mendesak untuk dipikirkan oleh stakeholder pendidikan. Secara aplikatif, diperlukan peningkatan profesionalisme guru karena guru merupakan pelaksana lapangan yang menjadi ujung tombak pendidikan. Berbagai upaya pemberdayaan dapat dilakukan di antaranya dengan pembinaan profesionalisme guru melalui pelatihan pembelajaran berbasis kompetensi (Lubis, 2010).

Pada kenyataannya pendidikan bukanlah merupakan suatu upaya yang sederhana, melainkan melalui suatu kegiatan yang dinamis dan penuh tantangan. Pendidikan akan selalu berubah seiring dengan perubahan jaman, setiap saat pendidikan selalu menjadi fokus perhatian dan bahkan tidak jarang menjadi sasaran ketidakpuasan karena pendidikan menyangkut kepentingan semua orang,bukan hanya menyangkut investasi dan kondisi kehidupan saat ini . Itulah sebabnya pendidikan senantiasa memerlukan upaya perbaikan dan peningkatansejalan dengan semakin tingginya kebutuhan dan tuntutan kehidupan masyarakat. Perbaikan tersebut membutuhkan supervisi kepala sekolah di setiap satuan pendidikan. Tidak adanya pelaksanaan supervisi kepala sekolah berpengaruh terhadap kompetensi guru dan mutu pendidikan (Sumarni et al., 2020).

Kunci utama keberhasilan pendidikan salah satunya terletak pada kualitas guru. Mengingat peran guru yang besar dalam proses pendidikan, kepala sekolahsebagai atasan langsung dituntut memiliki kapasitas utama sebagai edukator,manajer, administrator, supervisor, leader, inovator, dan motivator.Sementara itu guru memiliki tugas utama (1) membuat programpembelajaran; (2) melaksanakan program pembelajaran; melaksanakanevaluasi; (4) melaksanakan analisis hasil belajar siswa; melaksanakanperbaikan, remedial, dan pengayaan. Tidak semua guru mampu melaksanakantugas utama itu. Banyak faktor yang mempengaruhi. Dua faktor utama adalahkemampuan dan kemauan. Koordinat kemampuan dan kemauan akan sangat berpengaruh terhadap kinerja guru. Keduanya terletak pada kompetensi guru (Amran, 2015). Namun demikian Supriadi (2020) mendapati kepala PAUD memiliki peranan yang sangat 
penting agar penyelenggaraan pendidikan di sekolah berjalan dengan baik, efektif dan efisien. Dalam kondisi apapun peran kepala sekolah sebagai pemimpinan harus tetap dilaksanakan dengan baik.

Supervisi kepala sekolah dapat dikaitkan dengan upaya untuk mengendalikan program dan kegiatan pembelajaran, membina orang-orang yang melaksanakan program dan kegiatan yang dalam hal ini adalah guru, dan pelurusan program dan kegiatan yang tidak mengarah pada sasaran untuk tujuan pengendalian mutu. Oleh karena itu, pengawasan yang dilakukan kepala sekolah adalah kegiatan untuk menjamin tidak adanya penyimpanganpenyimpangan, terhindar dari kesalahan sekecil apapun, sehingga kegiatan sekolah dapat berjalan sesuai dengan yang telah direncanakan, mencapai sasaran yang ditetapkan dan mendapat pengakuan dari stakeholders (Evriani, 2017).

Kepala sekolah sebagai seorang pengawas disamping mengetahui jenis dan teknik supervisi dan teknik kepengawasan dari aspek manajerial, tetapi juga harus bertanggung jawab atas perbaikan dan peningkatan mutu akademik sekolah. Karena supervisi akademik merupakan kiat sekolah dalam rangka membina guru dalam peningkatan mutu proses pembelajaran. Sasaran supervisi akademik adalah guru dalam melaksanakan proses pembelajaran, yang terdiri dari materi pokok dalam proses pembelajaran, penyusunan silabus dan RPP, pemilihan strategi/ metode/ teknik pembelajaran, penggunaan media dan teknologi informasi dalam pembelajaran, menilai proses dan hasil pembelajaran serta penelitian tindakan kelas. Peningkatan kompetensi guru dalam memahami kompetensi pedagogik bisa didapat dari kesadaran mengenai betapa pentingnya penguasaaan aspek-aspek pedagogik dan pemahaman mengenai kompetensi pedagogik (Somantri, 2021). Menurut Octavianingrum (2020), kompetensi pedagogik pendidik itu juga sangat penting dalam menidentifikasi dan memahami karakteristik peserta didik. Hal ini bertujuan agar siswa merasa antusias dalam mengikuti proses pembelajaran. Kompetensi pedagogik guru yang baik sejak dini diharapkan meningkatkan kompetensi mutu pendidikan di masa yang akan datang.

Menurut Balqis et al. (2014) menyatakan bahwa kompetensi pedagogik pendidik meliputi kompetensi guru dalam perencanaan pembelajaran seperti menyusun rencana pembelajaran atau RPP/RKH. Selain itu, kompetensi pedagogik guru juga meliputi memahami dan memantapkan penguasaan materi pembelajaran seperti yang tertulis pada buku paket. Kompetensi pedagogik tersebut juga dicerminkan pada pengelolaan kelas baik dan pemanfaatan waktu dengan maksimal. Kompetensi pedagogik guru juga terwujud pada pemberian kesempatan bagi siswa untuk memanfaatkan fasilitas pembelajaran untuk mencapai tujuan pembelajaran. Selain itu, komptensi guru juga tercermin pada kemampuan guru dalam berkomunikasi dengan peserta didik untuk meningkatkan kualitas pembelajaran di dalam kelas.

Berdasarkan hasil penelitian awal di TK Dahlia Darmaji Kabupaten Lombok Tengah selama pandemic covid 19 ini mutu/ kualitas pendidikan menunjukkan hasil kurang memuaskan. Orang tua murid cenderung kurang puas dengan proses pembelajaran anaknya di TK Dahlia karena mereka beranggapan bahwa mutu pendidikan sekolah tersebut kurang baik dibandingkan TK negeri/ swasta lainnya yang sederajat di masa pandemic ini. Orang tua murid mengeluh karena tidak semua pendidik siswa serta orang tua siap dalam pembelajaran daring seperti saat ini. Ada persoalan kurangnya kompetensi guru dalam pemanfaatan teknologi dalam pembelajaran online pada jenjang taman kanak kanak yang belajar dengan bermain. Hasil observasi membuktikan bahwa dalam pembelajaran dikelas mayoritas guru kurang bisa menggunakan media dan model pembelajaran secara online yang relevan dengan materi yang diajarkan. Pengelolaan kelas belum terlaksana maksimal. Siswa diberi tugas lebih banyak dan kurangnya komunikasi antara guru dan siswa. Evaluasi hasil belajar siswa pun banyak yang tidak dikembalikan kembali kepada siswa, padahal hal tersebut sangat penting untuk bahan introspeksi dan motivasi siswa untuk lebih giat belajar. Dalam hal ini, hasil wawancara dengan guru menyatakan bahwa selama covid 19, Rencana Kegiatan Harian 
(RKH) disusun sendiri oleh guru sebelum proses pembelajaran dan belum didiskusikan dengan kepala sekolah. Keadaan seperti ini mengindikasikan bahwa kepala sekolah kurang mengawasi kegiatan guru, terutama dalam proses pengajaran. Berdasarkan kenyataan tersebut, tercermin pentingnya peran kepala sekolah dalam meningkatkan mutu pendidikan di TK Dahlia. Peran kepala sekolah melalui supervisi yang kuat diharapkan dapat membimbing, menjadi contoh, dan menggerakkan guru dalam peningkatan mutu pendidikan di masa Pandemi Covid 19 di TK Dahlia.

Pentingnya supervisi kepala sekolah telah diteliti oleh banyak ahli dalam bidang pendidikan. Suwartini (2017) menyatakan bahwa supervisi kepala sekolah dapat meningkatkan mutu pendidikan dan profesionalisme pendidik dalam dunia pendidikan. Henny (2021) juga menyatakan bahwa supervisi kepala sekolah dapat meningkatkan profesionalisme guru dalam melaksanakan tugas sebagai ujung tombak pendidikan. Dengan demikian, pengaruh supervisi kepala sekolah terhadap kompetensi pedagogik guru penting untuk untuk diteliti mengingat kompetensi pedagogik guru merupakan kompetensi yang wajib dimiliki oleh seorang pendidik. Hasil penelitian yang ada belum membahas tentang pengaruh supervisi kepala sekolah terhadap komptensi pedagogik guru.

\section{METODOLOGI}

Metode yang digunakan dalam penelitian ini adalah metode deskriptif korelasional, yaitu dimana suatu metode penelitian yang bertujuan menggambarkan dan memaparkan secara tepat keadaan tertentu dalam masyarakat/komunitas dengan suatu alat statistik yang dapat digunakan untuk membandingkan hasil pengukuran dua variabel yang berbeda agar dapat menentukan tingkat pengaruh antara variabel-variabel. Supervisi akademik oleh kepala sekolah sebagai variabel $X$ yang dapat memberikan pengaruh terhadap kompetensi pedagogik guru sebagai variabel Y. Penelitian ini menggunakan total sampling dalam penentuan jumlah sampel, yaitu seluruh guru di TK Dahlia Darmaji Kabupaten Lombok Tengah sebanyak 10 orang. Pengumpulan data primer dalam penelitian ini menggunakan teknik angket atau kuisioner yang merupakan suatu teknik pengumpulan data dengan cara membuat sejumlah pertanyaan yang diajukan kepada responden dengan maksud menjaring data dan informasi langsung dari responden yang bersangkutan.

Untuk mengukur setiap variabel penelitian menyusun instrumen bertolak pada indikator dari masing-masing variabel, kemudian dijabarkan pada butir-butir pertanyaan yang dilengkapi dengan pilihan alternatif jawaban dari masing-masing instrumen. Sebuah alat ukur dapat dinyatakan baik apabila mempunyai reliabilitas yang baik pula, yaitu ketepatan alat ukur. Hal ini dimaksudkan bahwa ketepatan alat ukur ini akan sangat berpengaruh dalam menentukan layak tidaknya suatu alat ukur untuk digunakan dalam penelitian ini, maka penulis mengadakan uji coba angket di luar responden dan menganalisisnya dengan teknik analisis non-tes. Analisis deskriptif, uji persyaratan dan pengujian hipotesis merupakan teknik analisis data penelitian ini. Teknik analisis data ini meliputi penyajian data meliputi ukuran data, dan ukuran penyebaran. penelitian ini menggunakan korelasi product-moment dalam pengujian hipotesis.

\section{HASIL DAN PEMBAHASAN}

Berdasarkan hasil analisis data, supervisi kepala sekolah berpengaruh dalam meningkatkan kompetensi pedagogi pendidik di TK Dahlia Darmaji Kabupaten Lombok Tengah di masa pandemi Covid 19. Hal ini dijabarkan pada penjelasan berikut:

\section{Supervisi Akademik Kepala Sekolah di TK Dahlia Darmaji Kabupaten Lombok Tengah}

Secara umum berdasarkan hasil angket kepada sampel dapat diketahui bahwa paling banyak guru berada pada posisi tingkat penilaian supervisi kepala sekolah di TK Dahlia Darmaji Kabupaten Lombok Tengah cukup baik atau 33,4\% dari jumlah sampel. Artinya bahwa kepala sekolah telah berusaha memaksimalkan kinerjanya terutama dalam hal 
supervisi akademik bagi para guru. Hasil ini sesuai dengan ketetapkan oleh Dirjen Peningkatan Mutu Pendidik dan Tenaga Kependidikan yang menyatakan bahwa, "Kompetensi supervisi akademik intinya adalah membina guru dalam meningkatkan mutu proses pembelajaran. Sasaran supervisi akademik adalah guru dalam melaksanakan proses pembelajaran,yang terdiri dari materi pokok dalam proses pembelajaran, penyusunansilabus dan RPP, pemilihan strategi/metode/ teknik pembelajaran, penggunaan media dan teknologi informasi dalam pembelajaran, menilai proses dan hasil pembelajaran serta penelitian tindakan kelas". Secara general, Tujuan dari supervisi akademik kepala sekolah adalah memberikan bantuan teknis dan bimbingan kepada guru (dan staf sekolah yang lain) agar personil tersebut mampu meningkatkan kualitas kinerjanya, terutama dalam melaksanakan proses belajar mengajar. Berdasarkan hasil penelitian (Evriani, 2017) menyatakan bahwa supervisi akademik kepala sekolah yang rendah dapat berpengaruh pada mutu pendidikan dan kompetensi guru. Selain itu menyebabkan kurangnya pengembangan diri setiap pendidik selama berkarir sebagai seorang guru.

Supervisi akademik kepala sekolah ini harus ditindak lanjuti oleh kepala sekolah. Berdasarkan hasil analisis data, tindak lanjut hasil supervisi akademik kepala sekolah masih kurang. Penting untuk meningkatkan tindak lanjut hasil supervisi akademik oleh kepala sekolah tersebut. Hal ini sesuai dengan hasil penelitian oleh Afriadi (2016) yang menyatakan bahwa bentuk tindak lanjut hasil supervisi akademik kepala sekolah dapat direalisasikan dengan mengevaluasi dan memberikan umpan balik kepada guru yang disupervisi melalui pembicaraan individual maupun berkelompok.

\section{Kompetensi Pedagogi Guru di TK Dahlia Darmaji Kabupaten Lombok Tengah}

Setelah guru diberikan mentoring dan evaluasi oleh kepala sekolah melalui kegiatan supervisi akademik. Secara umum hasil angket kepada sampel dapat diketahui bahwa kompetensi pedagogik guru di TK Dahlia Darmaji Kabupaten Lombok berada pada posisi sedang atau cukup baik $42 \%$ dari jumlah sampel. Perlu diberikan pengembangan kompetensi pedagogik guru di TK Dahlia Darmaji Kabupaten Lombok. Hal ini sangat beralasan karena peran guru sebagai ujung tombak mutu pendidikan di sekolah.

Berdasarkan hasil analisis data, kompetensi pedagogik guru di TK Dahlia Darmaji Kabupaten Lombok Tengah perlu ditingkatkan terutama dalam melakukan perencanaan pembelajaran. Kompetensi guru dalam menyusun rencana pembelajaran atau Rencana Kegiatan Harian/ RKH masih perlu dikembangkan. Terutama dalam menyusun langkah pembelajaran yang sesuai dengan tujuan pembelajaran. Sesuai dengan pendapat (Puspita, 2012) yang menyatakan bahwa program pembelajaran yang baik adalah pembelajaran yang terencana yang disesuaikan dengan kondisi anak dan lembaga pendidikan.

Selain itu, kompetensi pedagogik guru di TK Dahlia Darmaji Kabupaten Lombok Tengah dalam memahami dan memantapkan penguasaan materi pembelajaran masih perlu di eksplor lagi. Berdasarkan hasil analisis data, supervisi akademik oleh kepala sekolah memberikan masukan kepada guru dalam memantapkan penguasaan materi ajar. Hal ini ditemukan bahwa materi ajar yang disusun guru masih harus disempunakan sesuai dengan tujuan pembelajaran. Prabowo (2019) menyatakan bahwa materi ajar yang diajarkan oleh guru harus sesuai dengan tujuan pembelajaran dan kurikulum yang telah disusun. Guru diberikan masukan setelah proses supervisi diselesaikan di dalam kelas.

Selama proses supervisi kepala sekolah di TK Dahlia Darmaji Kabupaten Lombok Tengah ditemukan bahwa kompetensi pedagogik dalam pengelolaan kelas dan pemanfaatan waktu belum maksimal. Perlu ditingkat kompetensi pedagogik guru di TK Dahlia Darmaji Kabupaten Lombok Tengah. Sesuai denga pendapat Novauli (2021) yang menyatakan bahwa kompetensi pedagogik guru juga terwujud pada pemberian kesempatan bagi siswa untuk memanfaatkan fasilitas pembelajaran untuk mencapai tujuan pembelajaran. Selain itu, komptensi pedagogik guru juga tercermin pada kemampuan guru dalam berkomunikasi dengan peserta didik untuk meningkatkan kualitas pembelajaran di dalam kelas. Setelah 
proses supervisi akademik kepala sekolah, kemampuan guru dalam berkomunikasi dengan peserta didik juga harus ditingkatkan (Iskandar, 2019).

\section{Mutu layanan pendidikan di TK Dahlia Darmaji Kabupaten Lombok}

Secara umum berdasarkan hasil analisis data diketahui bahwa mutu layanan pendidikan di TK Dahlia Darmaji Kabupaten Lombok Tengah berada pada kategori tidak baik yaitu sebanyak 42,1\% dari jumlah reponden. Mutu pendidikan dapat dilihat dari seberapa optimal guru mampu memfasilitasi proses belajar siswa. Setiap tenaga pengajar memiliki tanggung jawab terhadap tingkat keberhasilan siswa belajar dan keberhasilan guru mengajar. Sementara itu dari sudut kurikulum dan bahan belajar mutu dapat dilihat dari seberapa luwes dan relevan kurikulum dan bahan belajar mampu menyediakan aneka stimulasi dan fasilitas belajar secara berdiversifikasi.

Hasil penelitian pada variabel mutu layanan menunjukan hasil yang tidak maksimal dimana katagori variabel ini adalah tidak baik. Hal ini disebabkan oleh kompetensi guru dan pengelolaan manajemen akademik oleh kepala sekolah yang belum dikembangkan secara maksimal. Mutu layanan pendidikan sangat bergantung pada guru sebagai ujung tombak pendidikan dan kepala sekolah sebagai supervisor akademik dari pembelajaran yang guru laksanakan, hal ini sesuai dengan PP No.19 Tahun 2005, dimana standar pendidik dan tenaga kependidikan diartikan sebagai "kriteria pendidikan prajabatan dan kelayakan fisik maupun mental (peserta pendidikan dalam jabatan)." Berdasarkan pernyataan di atas berarti seorang pendidik maupun tenaga kependidikan harus memiliki latar belakang pendidikan yang jelas dan lengkap, harus sehat jasmani dan rohani, serta memiliki profesionalisme yang terus dikembangkan agar dapat menghasilkan lulusan yang berkualitas (Suwartini, 2017).

Mutu layanan pendidikan sangat bergantung dengan profesionalisme guru juga didukung oleh pasal 1 Undang-Undang Nomor 14 Tahun 2005 Tentang Guru dan Dosen dijelaskan bahwa "Guru adalah pendidik profesional dengan tugas utama mendidik, mengajar, membimbing, mengarahkan, melatih, menilai, dan mengevaluasi peserta didik pada pendidikan anak usia dini jalur pendidikan formal, pendidikan dasar, dan pendidikan menengah". Guru sebagai figur sentral dalam pendidikan, haruslah dapat diteladani akhlaknya disamping kemampuan keilmuan dan akademisnya.

Selain itu, guru haruslah mempunyai tanggung jawab dan keagamaan untuk mendidik anak didiknya menjadi orang yang berilmu dan berakhlak. Mutu layanan pendidikan juga tidak lepas dari peran kepala sekolah yang dalam hal ini kaitannya dengan supervisi akademik. Henny (2021) menyatakan bahwa kompetensi supervisi akademik oleh kepala sekolah pada intinya merupakan pembinaan guru dalam meningkatkan mutu proses pembelajaran. Sasaran supervisi akademik adalah guru dalam melaksanakan proses pembelajaran". Tujuan umum dari supervisi akademik kepala sekolah adalah memberikan bantuan teknis dan bimbingan kepada guru (dan staf sekolah yang lain) agar personil tersebut mampu meningkatkan kualitas kinerjanya, terutama dalam melaksanakan proses belajar mengajar.

Pengaruh yang besar supervisi kepala sekolah terhadap kinerja guru(produktivitas kerja), mengisyaratkan bahwa supervisi kepala sekolah berperanansangat penting dalam menentukan kualitas kinerja guru di sekolah. Sehinggapelaksanaan kegiatan supervisi yang sistematis dan mendidik sangat perludilaksanakan dalam rangka peningkatan kualitas kinerja guru.Disisi lain tidak dapat dipungkiri bahwa seseorang belajar untukmeningkatkan kemampuannya dalam bekerja. Bertambahnya wawasan kependidikan dan perubahan pola pikir sebagai hasil belajar akan sangatberpengaruh positif terhadap peningkatan kualitas kinerja guru (Henny, 2021). Oleh sebab itu guru harus selalu berusaha meningkatkan kompetensi pedagogiknya melaluipeningkatan jenjang pendidikan. Karena dengan dengan ditunjang supervisekepala sekolah yang baik dan semakin meningkatnya kompetensi pedagogik akanber pengaruh secara positif terhadap kinerja guru. 


\section{SIMPULAN}

Supervisi Kepala Sekolah berpengaruh dalam meningkatkan kompetensi pedagogi pendidik di masa pandemi Covid 19 di TK Dahlia Darmaji Kabupaten Lombok. Hal ini berdasarkan pada temuan bahwa 1) Supervisi akademik kepala sekolah mempunyai pengaruh positif terhadap kompetensi pedagogi guru yaitu pada posisi cukup baik. Hal ini tercermin pada indikator kompetensi pedagogi guru yaitu adanya peningkatan kemampuan guru dalam menyusun perencanaan pembelajaran, memahami dan memantapkan penguasaan materi pembelajaran, pengelolaan kelas dan pemanfaatan waktu, dan berkomunikasi dengan peserta didik dengan baik. 2) Supervisi akademik kepala sekolah juga mempengaruhi mutu layanan pendidikan di TK Dahlia Darmaji Kabupaten Lombok. Supervisi akademik kepala sekolah yang baik dab berkelanjutan akan memberikan kecenderungan mutu layanan pendidikan dan kompetensi pedagogi guru di TK Dahlia yang baik juga.

\section{UCAPAN TERIMAKASIH}

Penulis mengucapkan terima kasih kepada kepada sekolah TK Darmaji Kabupaten Lombok dan semua responden pada penelitian ini. Editor dan reviewer Jurnal Obsesi: Jurnal Pendidikan Anak Usia Dini atas masukannya sehingga artikel ini dapat dipublikasikan.

\section{DAFTAR PUSTAKA}

Afriadi, A. et al. (2016). Kompetensi supervisi kepala sekolah merupakan salah faktor yang mempengaruhi peningkatan profesionalisme guru. Jurnal Administrasi Pendidikan, $4(2), 14-21$.

Amran, amran. (2015). Faktor Penentu Keberhasilan Pengelolaan Satuan Pendidikan. Manajer Pendidikan, 9(2), 185-196.

Balqis, P., Usman, N., \& Ibrahim, S. (2014). Kompetensi Pedagogik Guru Dalam Meningkatkan Motivasi Belajar Siswa Pada. Jurnal Administrasi Pendidikan Pascasarjana Univeritas Syiah Kuala, 2(1), 25-38.

Das, S. W. H. (2015). Implementasi kurikulum pendidikan agama islam berbasis kompetensi pada taman kanak-kanak (. Istiqra', II(2), 198-207.

Evriani, L. (2017). Supervisi akademik kepala sekolah Dalam upaya membantu guru mengatasi kesulitan mengajar di SMP. Manajer Pendidikan, 11.

Henny, H. (2021). Supervisi Kepala Sekolah Dalam Meningkatkan Profesional Guru Pada Sma Methodist Kota Banda Aceh. Angewandte Chemie International Edition, 6(11), 951952., 2013-2015.

Iskandar, W. (2019). Kemampuan Guru Dalam Berkomunikasi Terhadap Peningkatkan Minat Belajar Siswa di SDIT Ummi Darussalam Bandar Setia. AR-RIAYAH: Jurnal Pendidikan Dasar, 3(2), 135. https:// doi.org/10.29240/jpd.v3i2.1126

Lubis, S. A. (2010). Konseling Islami : Rumusan Konseptual. Miqot, XXXIV(1), 91-106.

Novauli, F. (2021). Kompetensi guru dalam peningkatan prestasi belajar Pada smp negeri dalam kota banda aceh. Jurnal Pendidikan Sejarah Indonesia, 4(1), 1. https:// doi.org/10.17977/um0330v4i1p1-8

Octavianingrum, D. (2020). Pentingnya Kompetensi Pedagogik Dalam Kegiatan Magang Kependidikan Bagi Mahasiswa Calon Guru. Jurnal Ilmiah Kependidikan, Vol 7(No 2), 115-124 hlm.

Prabowo, H. (2019). Pentingnya Peranan Kurikulum Yang Sesuai Dalam Pendidikan. 1-10.

Puspita, E. (2012). Menyusun Perencanaan Pembelajaran AUD. Jurnal Educhild, 01(1), 67-76.

Somantri, D. (2021). Pentingnya Kompetensi Pedagogik Guru. JPG: Jurnal Pendidikan Guru, 2(1), 23. https:// doi.org/10.32832/jpg.v2i1.4099

Sumarni, S., Babo, R., \& Muhlis, M. (2020). Publish By Primary : Jurnal Pendidikan Guru Sekolah Dasar Volume 9 Nomor 2 April 2020. 
Supriadi, O. (2020). Peranan Kepala PAUD dalam Penyelenggaraan Pendidikan Sebelum dan Saat Terjadi Pandemi Covid-19. Jurnal Obsesi : Jurnal Pendidikan Anak Usia Dini, 5(1), 841-856. https://doi.org/10.31004/obsesi.v5i1.727

Suwartini, E. A. (2017). Supervisi Akademik Kepala Sekolah, Profesionalisme Guru Dan Mutu Pendidikan. Jurnal Administrasi Pendidikan, 24(2), 62-70. https://doi.org/10.17509/jap.v24i2.8294

Warmansyah, J. (2020). Program Intervensi Kembali Bersekolah Anak Usia Dini Masa Pandemi Covid-19. Jurnal Obsesi: Jurnal Pendidikan Anak Usia Dini, 5(1), 743. https://doi.org/10.31004/obsesi.v5i1.573

Wiresti, R. D. (2020). Analisis Dampak Work From Home pada Anak Usia Dini di Masa Pandemi Covid-19. Jurnal Obsesi: Jurnal Pendidikan Anak Usia Dini, 5(1), 641. https://doi.org/10.31004/obsesi.v5i1.563 